\title{
DESIGN IMPROVEMENT OF THE CAR FRONTAL PROTECTION SYSTEM
}

\author{
POHLAK, M.; MAJAK, J. \& EERME, M.
}

Abstract: Aim of the current study is to design the extra frontal protection system of car satisfying the requirements of directive 2005/66/EC of the European Parliament and of the Council. From point of view of the current study the car frontal protection system is treated as additional energy absorbing element. Main attention is paid to the optimal design of fastening components. Multi-criteria optimal design problem is formulated and the necessary optimality conditions are derived. An algorithm proposed for solution of the considered optimization problem is based on the use of FEA system (LS-DYNA, LS-OPT) and MATLAB Toolboxes (Neural network, Optimization). An analysis of car-pedestrian crash situation is performed by use of explicit solver and the following stiffness analysis with implicit solver. For modeling response surface and search for optimal solution both LS-OPT and MATLAB Toolboxes are used. The experimental validation of the models designed is performed.

Key words: optimal design, crash simulation, energy absorption
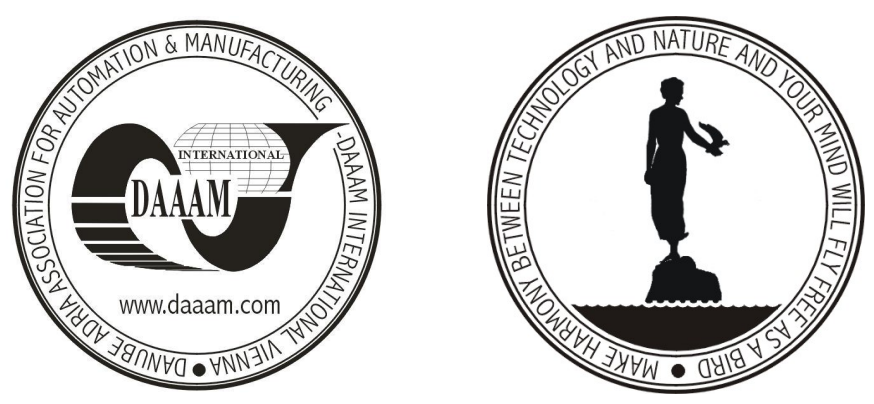

Authors' data: Dr.Sci. Math. Pohlak, M[eelis]; PhD. Majak, J[ueri]; PhD. Eerme, M[artin], Tallinn University of Technology, Ehitajate tee 5, 19086 Tallinn, Estonia, jmajak@staff.ttu.ee, meelisp@staff.ttu.ee, eerme@staff.ttu.ee

This Publication has to be referred as: Pohlak, M.; Majak, J. \& Eerme, M. (2007). Design Improvement of the Car Frontal Protection System, Chapter 45 in DAAAM International Scientific Book 2007, B. Katalinic (Ed.), Published by DAAAM International, ISBN 3-901509-60-7, ISSN 1726-9687, Vienna, Austria

DOI: $10.2507 /$ daaam.scibook.2007.45 